\title{
Knowledge, attitude and practice towards management of orthodontic emergency during COVID-19 pandemic among orthodontic professionals
}

\author{
Dr Sanjay Prasad Gupta', Dr Shristi Rauniyar² \\ 'Orthodontics and Dentofacial Orthopedics unit, Department of Dentistry, \\ Tribhuvan University Teaching Hospital, Institute of Medicine, Tribhuvan University, Kathmandu, Nepal \\ ${ }^{2}$ Dental Villa-Orthodontic center \& speciality dental clinic, Kathmandu \\ Corresponding author: Dr Sanjay Prasad Gupta, Email: sanjayagupta2000@gmail.com
}

\section{ABSTRACT}

Introduction: An orthodontic emergency is a problem arising from an orthodontic appliance and the patient may experience pain and discomfort, where an unscheduled appointment might be required to resolve the issue. Dental care settings invariably carry the risk of SARS-CoV-2 infection due to the nature of procedures performed. The aim of this study was to assess the knowledge, attitude and practice towards management of orthodontic emergency during COVID-19 pandemic among orthodontic professionals.

Materials and Method: In this descriptive cross sectional study, evaluation of the knowledge, attitude and practice towards management of orthodontic emergency during COVID-19 pandemic were done by administering the online semi-structured questionnaire consisting of 20 questions to 120 orthodontic professionals of the Nepal through online platforms. The filled online forms were then documented for further evaluation.

Result: This study found that among the total of 120 participants, $74(61.66 \%)$ were male while $46(38.33 \%)$ were female. The mean age of the participants was $36.4 \pm 6.45$ years while mean years of experiences was $6.15 \pm 5.55$ years. Most of the orthodontists think that poking distal wire or ligature wire ( $87.5 \%)$ followed by periodontal abscess ( $85.8 \%$ ) around the loose band as the most common orthodontic emergencies. Majority of the orthodontists recommended that, the patient should be triaged by telephone or through video call $(79.1 \%)$, ask the patient to take picture and send to identify the type of problem (74.1\%) while offer any interim self-care advise to solve the problem (58.3\%) before face to face consultation. Around $57.5 \%$ of orthodontists were practicing only for urgent and emergency cases during this pandemic and lockdown.

Conclusion: This study showed that most of the orthodontic professionals had adequate knowledge about orthodontic emergency problems and had positive attitude towards their profession but the practice was limited due to COVID-19 pandemic and the risks involved in this.

KEYWORDS: Attitude, COVID-19, Knowledge, Orthodontic emergency, Orthodontic professionals, Practice

\section{INTRODUCTION}

An orthodontic emergency is described as a problem arising from an orthodontic appliance, where an unscheduled appointment is required to resolve the issue. When a patient has such an issue, a timely additional appointment may need to be arranged with a specialist. Patients who present with an orthodontic emergency may be experiencing pain or discomfort.

The word "emergency" sounds something urgent and critical in the medical profession, but the orthodontic patients do not deserve such crucial attention, ${ }^{2}$ hence, better to refer as casual attender. ${ }^{3}$ Although few unscheduled arrivals of patients are anticipated, increased frequency bothers both the patient and the clinician. The orthodontic emergency can also be inconvenient for the patient and parents in attending for an additional, unexpected appointment due to preexisting school or work commitments. 
A wide range of unscheduled appointments has been reported by various researchers in the hospital-based audits. ${ }^{4,5}$ Some authors even discovered that almost half of the orthodontic appointments were dedicated to repair dislodged bands, ligatures, or management of soft tissue trauma. ${ }^{6}$ Bashir shares his experience of sparing an extra day for every 10 working days to manage repair appointments. ${ }^{7}$ It is believed that $90 \%$ of problems are caused by $10 \%$ of the orthodontic patients and those are referred as "wreckers." 8

Consequently, repeated breakages prolong treatment time and can lead to decreased patient motivation due to a loss of confidence in the appliance or the operator. By providing appropriate timely management, inconvenience and distress to both the patient and parents may be minimized with the efficacy of the appliance still being maintained.

Dental care settings invariably carry the risk of SARSCoV-2 infection due to the nature of procedures performed. In the dental field, for the purpose of controlling Corona virus disease 2019 (COVID-19), the fundamental preventive measure lies in the filter of patients who come to the ambulatory. Therefore, a questionnaire should be used to screen patients with potential infection of SARS-CoV-2 before they could be led to the dental chair-side, as recently suggested. ${ }^{9}$ Another fundamental aspect is the correct use of personal protective equipment (PPE) and the strict compliance with the behavioral guidelines at the dental office.

Given that the professional can assess whether to stay open or manage emergencies only, common sense must prevail during the time of COVID-19 pandemic. One choice that can be made is to postpone routine orthodontic appointments, but patients need to be assured and followed, especially if they are experiencing discomfort or problems related to the orthodontic appliance they are using.

During the COVID-19 pandemic, it is advised that any patient requesting urgent care should first be triaged by telephone or online video-link by an orthodontist to assess the clinical urgency, establish their COVID-19 risk, offer any interim self-care advice and make an appointment for face-to-face assessment if absolutely necessary. ${ }^{10}$
Healthcare providers should be trained to use modern web-based communication systems with accurate assessment of indications and contraindications as it is very useful in this digital era. ${ }^{11,12}$

Almost all orthodontic emergencies can be managed via appropriate advice from a suitably qualified health care professional. Only acute or urgent emergencies should be offered an appointment. ${ }^{13}$ While providing treatment to the patient, it is recommended that no aerosol generating procedures are undertaken in orthodontic emergency patients. Treatment should be restricted to the trimming and adjustment of wires that are causing trauma as simply as possible with appropriate pliers (distal end cutter or wire cutters with forceps) or simple removal of any loose appliance component. ${ }^{2}$

The aim of the present study was to evaluate the knowledge, attitude and practice towards management of orthodontic emergency during COVID-19 pandemic among orthodontic professionals. This study was conducted to fill this lacuna and it is hoped that these findings will be beneficial for future research as well as to enhance the knowledge, attitude and practice among orthodontic professionals in coming days.

\section{MATERIALS AND METHOD}

In this cross-sectional descriptive study, the knowledge, attitude and practice towards management of orthodontic emergency during COVID-19 pandemic was assessed by administering the online questionnaire to 120 registered orthodontic professionals of the Nepal through online platforms like emails by using the google form.

Ethical approval was obtained from institutional review committee of Institute of Medicine before conducting this study (Ref. 396 (6-11)E2 076/077).

In this study orthodontic professionals of Nepal who received speciality registration from Nepal Medical Council were included, whereas orthodontic professionals not residing in Nepal were excluded from this study.

In this online survey form, informed consent were taken from the each respondent, by clearly explaining the objectives of the study and confidentiality of data will be assured to them. 
Knowledge, attitude and practices towards management of orthodontic emergency during COVID-19 pandemic were evaluated by adopting semi-structured questionnaire for collecting data, which consists of total 20 questions- out of which 5 for demographic information, 5 for knowledge, 5 for attitude and 5 for practice related questions.

Data obtained were transferred to MS-excel sheet. The data were verified and analysed statistically using SPSS Statistics Version 21.0 (Armonk, NY: IBM Corp.) with confidence level set at $95 \%(P<0.05)$ to test for significance. Socio-demographic and other quantitative data were summarized and presented using numbers and percentage.

\section{RESULT}

This study found that among the total of 120 participants, $74(61.66 \%)$ were male while $46(38.33 \%)$ were female (Fig. 1).

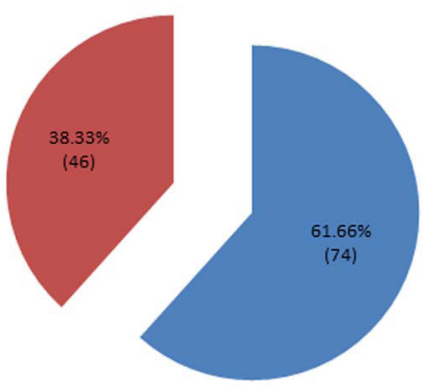

Fig. 1 Frequency of gender distribution

The mean age of the participants was $36.4 \pm 6.45$ years while mean years of experiences was $6.15 \pm 5.55$ years (Table 1).

Table 1: Age of the participants and years of experiences

\begin{tabular}{|l|l|}
\hline Age of the participants & Years \\
\hline Minimum age & 27 years \\
\hline Maximum age & 68 years \\
\hline Mean age & $36.4 \pm 6.45$ years \\
\hline Years of experiences & \\
\hline Minimum & $<1$ year \\
\hline Maximum & 30 years \\
\hline Mean years of experiences & $6.15 \pm 5.55$ years \\
\hline
\end{tabular}

The other demographic distribution of the participants like working place and location of practice is summarized in Table 2.

Table 2: Demographic distribution of the participants:

\begin{tabular}{|l|l|}
\hline Particulars/ Variables & $\mathbf{n}(\%)$ \\
\hline Working place & \\
\hline Private Clinic & $53(44.16 \%)$ \\
\hline Private Hospital & $12(10 \%)$ \\
\hline Medical/Dental College & $42(35 \%)$ \\
\hline Government Hospital & $13(10.83 \%)$ \\
\hline Total & $120(100 \%)$ \\
\hline Location of practice & \\
\hline Province 1 & $8(6.66 \%)$ \\
\hline Province 2 & $6(5 \%)$ \\
\hline Province 3 (Bagmati Pradesh) & $85(70.83 \%)$ \\
\hline Province 4 (Gandaki Pradesh) & $6(5 \%)$ \\
\hline Province 5 & $12(10 \%)$ \\
\hline Province 6 (Karnali Pradesh) & - \\
\hline $\begin{array}{l}\text { Province 7 (Sudurpaschim } \\
\text { Pradesh) }\end{array}$ & $3(2.5 \%)$ \\
\hline Total & $120(100 \%)$ \\
\hline
\end{tabular}

In this study, most of the orthodontists think that poking distal wire or ligature wire $(87.5 \%)$ followed by periodontal abscess (85.8\%) around the loose band as the most common orthodontic emergencies. Most of the orthodontists $(75.8 \%)$ have not received any training or courses about how to deal with patients during any pandemic. All the orthodontists (100\%) are aware of the mode of transmission of COVID-19. Majority of the orthodontists recommended that, the patient should be triaged by telephone or through video call (79.1\%), ask the patient to take picture and send to identify the type of problem $(74.1 \%)$ while offer any interim self care advise $(58.3 \%)$ to solve the problem before face to face consultation. Most of the orthodontists are aware of regarding the restriction of parents and/or siblings to access the clinic area to minimize the risk of spread of infection during this pandemic (Table 3). 
Table 3: Questions regarding knowledge

\begin{tabular}{|c|c|c|}
\hline Questions & Response & n (\%) \\
\hline \multirow{4}{*}{$\begin{array}{l}\text { 1. Which of the following are } \\
\text { considered orthodontic } \\
\text { emergencies? }\end{array}$} & Loose bracket & $25(20.8 \%)$ \\
\hline & Poking distal wire or ligature wire & $105(87.5 \%)$ \\
\hline & Periodontal abscess around loose band & $103(85.8 \%)$ \\
\hline & Retainer or functional appliance is broken or lost or does not fit & $53(44.1 \%)$ \\
\hline \multirow{4}{*}{$\begin{array}{l}\text { 2. Have you been received any } \\
\text { training or courses about how } \\
\text { to deal with patients during any } \\
\text { pandemic? }\end{array}$} & None & $3(2.5 \%)$ \\
\hline & Yes & $22(18.3 \%)$ \\
\hline & No & $91(75.8 \%)$ \\
\hline & Not sure & $7(5.8 \%)$ \\
\hline \multirow{3}{*}{$\begin{array}{l}\text { 3. Are you aware of the mode of } \\
\text { transmission of COVID-19? }\end{array}$} & Yes & $120(100 \%)$ \\
\hline & No & - \\
\hline & Don't know & - \\
\hline \multirow{4}{*}{$\begin{array}{l}\text { 4. To do before providing urgent } \\
\text { face to face care to the patient } \\
\text { during COVID-19 pandemic }\end{array}$} & Triaged by telephone or through video call & $95(79.1 \%)$ \\
\hline & Ask the patient to take picture and send & $89(74.1 \%)$ \\
\hline & Offer any interim self-care advice & $70(58.3 \%)$ \\
\hline & Advise them to come directly to the hospital & $4(3.3 \%)$ \\
\hline \multirow{3}{*}{$\begin{array}{l}\text { 5. Regarding restriction of parent } \\
\text { and/or sibling to access the clinic } \\
\text { area. }\end{array}$} & Only the patient is allowed into the clinic area & $107(89.1 \%)$ \\
\hline & Allowing a parent to accompany younger patients & $57(47.5 \%)$ \\
\hline & $\begin{array}{l}\text { Not restricting the number of individuals accompanying } \\
\text { patients }\end{array}$ & $1(0.83 \%)$ \\
\hline
\end{tabular}

Most of the orthodontists are agreed that orthodontist should have a role in health education services by extending the information on prevention measures for COVID-19. Many prefer to treat just emergency and urgent cases and postpone other routine cases. Most of the orthodontists think that debonding with air turbine or electric hand piece and use of three way airwater syringe should be avoided to minimize the spread of infection during this pandemic. Many orthodontists (88.3\%) have plan to change the cleaning/disinfection practice in their center (Table 4).

Table 4: Questions regarding attitude

\begin{tabular}{|c|c|c|}
\hline Questions & Response & $\mathrm{n}(\%)$ \\
\hline \multirow{5}{*}{$\begin{array}{l}\text { 1. Orthodontist should have a role } \\
\text { in health education services by } \\
\text { extending the information on } \\
\text { prevention measures for COVID-19. }\end{array}$} & Strongly disagree & - \\
\hline & Disagree & - \\
\hline & Neutral & $5(4.1 \%)$ \\
\hline & Agree & $56(46.6 \%)$ \\
\hline & Strongly agree & $59(49.1 \%)$ \\
\hline \multirow{5}{*}{$\begin{array}{l}\text { 2. I prefer to treat just emergency and } \\
\text { urgent cases and postpone other } \\
\text { cases. }\end{array}$} & Strongly disagree & - \\
\hline & Disagree & $2(1.6 \%)$ \\
\hline & Neutral & $5(4.1 \%)$ \\
\hline & Agree & $46(38.3 \%)$ \\
\hline & Strongly agree & $67(55.8 \%)$ \\
\hline
\end{tabular}




\begin{tabular}{|l|l|l|}
\hline Questions & Response & $\mathbf{n}(\%)$ \\
\hline \multirow{4}{*}{\begin{tabular}{l} 
3. $\begin{array}{l}\text { Orthodontist should avoid debonding } \\
\text { with air turbine or electric hand piece. }\end{array}$ \\
\cline { 2 - 3 }
\end{tabular}} & Strongly disagree & $1(0.83 \%)$ \\
\cline { 2 - 3 } & Disagree & $6(5 \%)$ \\
\cline { 2 - 3 } & Neutral & $56(46.6 \%)$ \\
\cline { 2 - 3 } & Agree & $57(47.5 \%)$ \\
\cline { 2 - 3 } & Strongly agree & - \\
\hline \multirow{4}{*}{$\begin{array}{l}\text { Orthodontist should avoid use of three } \\
\text { way air- water syringe. }\end{array}$} & Strongly disagree & $1(0.83 \%)$ \\
\cline { 2 - 3 } & Disagree & $5(4.1 \%)$ \\
\cline { 2 - 3 } & Neutral & $14(11.6 \%)$ \\
\cline { 2 - 3 } & Agree & $55(45.8 \%)$ \\
\cline { 2 - 3 } & Strongly agree & $67(55.8 \%)$ \\
\hline \multirow{3}{*}{$\begin{array}{l}\text { Will you change the cleaning/ } \\
\text { disinfection practice in your center? }\end{array}$} & Yes & $106(88.3 \%)$ \\
\cline { 2 - 3 } & No & $14(11.6 \%)$ \\
\hline
\end{tabular}

Around $57.5 \%$ of orthodontists were practicing during lockdown only for urgent and emergency cases while $36.6 \%$ were not practicing during lockdown.

Most of the orthodontists (58.3\%) used telephone/ online as a method of consultation to the patients while $36.6 \%$ were consulted patients both physically as well as through telephone/online. Almost all (89.9\%) were aware of the current CDC or WHO Guidelines for cross-infection control regarding COVID-19. Most of the orthodontists $(67.5 \%)$ were working fewer hours due to their own decision while $21.6 \%$ were working fewer hours at employer's behest. Around $70 \%$ orthodontists seek out national/regional/local news 2-5 times a day about COVID-19 (Table 5).

Table 5: Questions regarding practice

\begin{tabular}{|l|l|l|}
\hline Questions & Response & $\mathrm{n}(\%)$ \\
\hline \multirow{4}{*}{$\begin{array}{l}\text { 1. Are you currently practicing during } \\
\text { lock-down? }\end{array}$} & Yes & $7(5.8 \%)$ \\
\cline { 2 - 3 } & No & $44(36.6 \%)$ \\
\cline { 2 - 3 } & Only for urgent and emergency cases & $69(57.5 \%)$ \\
\hline \multirow{4}{*}{$\begin{array}{l}\text { 2. What was the method of } \\
\text { consultation? }\end{array}$} & Physically & $1(0.83 \%)$ \\
\cline { 2 - 3 } & By telephone/online & $70(58.3 \%)$ \\
\cline { 2 - 3 } & Both & $44(36.6 \%)$ \\
\cline { 2 - 3 } $\begin{array}{l}\text { Are you updated with the current CDC } \\
\text { control regarding COVID-19? }\end{array}$ & None & $5(4.1 \%)$ \\
\cline { 2 - 3 } & Yes & $107(89.1 \%)$ \\
\cline { 2 - 3 } & No & $10(8.3 \%)$ \\
\cline { 2 - 3 } & Don't Know & $3(2.5 \%)$ \\
\hline \multirow{3}{*}{ 4. Has your work schedule changed? } & Yes, I am working extra hours & $1(0.83 \%)$ \\
\cline { 2 - 3 } & $\begin{array}{l}\text { Yes, I am working fewer hours and that is my own } \\
\text { decision }\end{array}$ & $81(67.5 \%)$ \\
\cline { 2 - 3 } & Yes, I am working fewer hours at my employer's behest & $26(21.6 \%)$ \\
\cline { 2 - 3 } & No, my work schedule has not changed & $12(10 \%)$ \\
\hline
\end{tabular}




\begin{tabular}{|l|l|l|}
\hline Questions & Response & $\mathrm{n}(\%)$ \\
\hline \multirow{3}{*}{$\begin{array}{l}\text { 5. Do you seek out national/regional/ } \\
\text { local news about COVID-19? }\end{array}$} & More than 5 times a day & $18(15 \%)$ \\
\cline { 2 - 3 } & Between 2-5 times a day & $84(70 \%)$ \\
\cline { 2 - 3 } & Once a day & - \\
\cline { 2 - 3 } & Every few days & $16(13.3 \%)$ \\
\cline { 2 - 3 } & None & $2(1.6 \%)$ \\
\hline
\end{tabular}

\section{DISCUSSION}

There are varieties of reasons for which patients appear for emergency appointments. These include dislodged brackets and tubes; loose bands; tearing of bands; weld failure; trauma due to extraoral appliance; soft tissue trauma with archwire, ligature wire, or bracket hooks; repair/adjustment of retainers; and dislodged module/ elastomeric chain/ligature wire. In the fixed orthodontic treatment, the most frequent reason of surprise visit is the repair of the debonded brackets with tendency of breakage higher in some teeth than the other. ${ }^{14}$

In this study, most of the orthodontists think that poking distal wire or ligature wire (87.5\%) followed by periodontal abscess (85.8\%) around the loose band followed by as the most common orthodontic emergencies while only $20.8 \%$ of the orthodontists think that loose bracket may cause the orthodontic emergency. Though this is an orthodontists perception, this finding is contradictory to the findings of one Nepalese clinical study, where the most common reason for emergency appointments was the loosening of brackets or bondable buccal tubes followed by the loosening of bands. ${ }^{15}$

Orthodontic appliances, besides the ill-fitting prosthesis, are supposed to be one of the major causes of physical iatrogenic injuries to the intra- and extra-oral tissues, leading patients to report back to the clinician. ${ }^{16}$ Frequent visits may lead to loss of confidence and breach of doctor-patient relationship. ${ }^{17}$ In addition, breakages often lead to an overall increase in treatment duration which results in a greater potential for iatrogenic damage.

The prime modes of containing this pandemic are enforcing effective social/physical distancing and use of masks but unfortunately it is not possible during carrying the dental procedures. Dental teams are at high risk of contracting the virus and potentially transmitting the SARS-CoV-2 virus due to the nature of dentistry practice, ${ }^{9}$ specificity of its procedures, which involves face-to-face close contact, unable to worn masks by the patient during dental treatment, and frequent exposure to saliva, blood, and other body fluids, and the handling of sharp instruments.

Many dental procedures including orthodontic procedure produce aerosols and droplets that are contaminated with virus. ${ }^{18}$ Dental devices such as highspeed dental handpiece uses high-speed air to drive the turbine to rotate at high speed and work with running water. It is hard to avoid the generation of large amounts of aerosol and droplet mixed with patient's saliva and even blood during use of dental devices. ${ }^{19}$

The pathogenic microorganisms can be transmitted in dental settings through inhalation of airborne microorganisms that can remain suspended in the air for long periods ${ }^{20}$ direct contact with blood, oral fluids, or other patient materials, ${ }^{21}$ contact of conjunctival, nasal, or oral mucosa with droplets and aerosols containing microorganisms generated from an infected individual and propelled a short distance by coughing and talking without a mask, ${ }^{19,22}$ and indirect contact with contaminated instruments and/or environmental surfaces. ${ }^{23}$ Infections could be present through any of these conditions involved in an infected individual in dental clinics and hospitals, especially during COVID-19 pandemic.

It has been confirmed that those without symptoms can still spread the virus. This makes it extremely difficult to identify those individuals that pose a risk..$^{9}$ Owing to the contagious nature of the disease, while we take a history and carry out an examination of the patient and assess for urgency of dental need, an asymptomatic patient could have acted as a potent source of infection for others.

Since the health care workers themselves fall in the 
high risk group for infection, exposure to them and to the health care settings is best avoided or postponed to control community spread. As per an earlier report in the early stage of the epidemic, on an analysis of hospitalized patients with SARS-CoV-2, $41 \%$ were presumed to have been infected in hospital, including $29 \%$ health care workers and $12 \%$ patients. ${ }^{24}$

Center for disease control 2020 (CDC 2020) has provided guideline to dental offices does not distinguish between the multiple dental specialties. ${ }^{25}$

During COVID-19 pandemic, It is recommended that dentists should accept in the private practice only nondeferrable urgencies, such as an abscess or irreversible pulpitis. Orthodontic problems, like general dentistry problems, represent urgencies, not true emergencies, so a video call or message with a photo might be the best options to evaluate the case. ${ }^{10}$

Almost all orthodontic emergencies can be managed via appropriate advice from a suitably qualified health care professional. Only acute or urgent emergencies should be offered an appointment.

A bracket may become loose or lose its metallic or elastic ligature as a consequence of eating hard or sticky foods: if the bracket remains flush with the tooth, it can be left as it is, if it seems to fall from the archwire, the patient can carefully try to remove it with eyebrow tweezers. If there is a metallic ligature that causes soft tissue trauma or pain, the patient should try to push it back with the small eraser on the back of a pencil. In the event that it is not possible, then orthodontic relief wax can be applied. Another very frequent problem, especially during the first phases of the treatment, is protruding distal ends of archwire that can cause soft tissue trauma and large and painful ulcers. If the archwire has slid round to one side, then it may be possible to reposition it with the help of eyebrow tweezers. If the patient is not able to reposition the wire, the best option is to cut it. Thin wires can be cut using a nail clipper. Disinfection can be performed by boiling the instrument in $100{ }^{\circ} \mathrm{C}$ water for $30 \mathrm{~min} .{ }^{26,27} \mathrm{In}$ any case of soft tissue trauma caused by sharp objects (end of the wire or ligatures), orthodontic relief wax is a good momentary solution.

Finding of this study also showed that majority of the orthodontists recommended that, the patient should be triaged by telephone or through video call ( $79.1 \%)$, ask the patient to take picture and send to identify the type of problem $(74.1 \%)$ while offer any interim self care advise $(58.3 \%)$ to solve the problem before face to face consultation.

In this study, around $57.5 \%$ of orthodontists were practicing during lockdown only for urgent and emergency cases while $36.6 \%$ were not practicing during lockdown. Most of the orthodontists (58.3\%) used telephone/online as a method of consultation to the patients while $36.6 \%$ were consulted patients both physically as well as through telephone/online.

As a health care professionals, it is our duty to mitigate the community spread of this disease through responsible and informed actions. We need to fulfill our professional duty towards our patients, and in particular obtain informed consent from the patient of the proposed treatments, while keeping ourselves, our staff and environment safe.

\section{CONCLUSION}

This study showed that most of the orthodontic professionals had adequate knowledge about orthodontic emergency problems and had positive attitude towards their profession but the practice was limited due to COVID-19 pandemic and the risks involved in this.

\section{ACKNOWLEDGEMENTS}

We would like to thank all the orthodontic professionals of Nepal who have given their valuable time and agreed to participate in this study.

\section{CONFLICT OF INTEREST}

The author declares that there is no conflict of interest regarding the publication of this paper. 


\section{REFERENCES}

1. Caprioglio A, Pizzetti GB., Zecca PA, Fastuca R, Giuliano M and Nanda R. Management of orthodontic emergencies during 2019-NCOV. Prog Orthod. 2020;21(10):1-4.

2. Gottlieb E. Most orthodontic emergencies are not emergencies at all. J Pract Orthod 1969;3:335-6.

3. Oliver R. The casual attender. Br J Orthod 1982;9:154-7.

4. Sayers M, Khoshkhounejad G, Patel H, Hodges S. Audit on orthodontic casualties. BOS Clin Effect Bull 2006;19:20-1.

5. Thickett E, Power S. Fixed appliance breakages the ongoing audit cycle. BOS Clin Effect Bull 2007;20:22-3.

6. Bashir U. Reduce repair appointments. Pak Orthod J 2013;5:1.

7. Thickett E, Power S. Fixed appliance breakages the ongoing audit cycle. BOS Clin Effect Bull 2007;20:22-3.

8. Dowsing P, Murray A, Sandler J. Emergencies in orthodontics. Part 1: Management of general orthodontic problems as well as common problems with fixed appliances. Dent Update 2015;42:131-4, 137-40.

9. Peng X, Xu X, Li Y, Cheng L, Zhou X, Ren B. Transmission routes of 2019-nCoV and controls in dental practice. Int J Oral Sci. 2020 Mar 3;12(1):9.

10. Popat $\mathrm{H}$, Thomas K, Farnell DJ. Management of orthodontic emergencies in primary care- self-reported confidence of general dental practitioners. Br Dent J. 2016 Jul 8;221(1):21-4.

11. Veneroni L, Ferrari A, Acerra S, Massimino M, Clerici CA. Considerazioni sull'uso di WhatsApp nella comunicazione e relazione medicopaziente. Recenti Prog Med, 106: 331-6.

12. Mars M, Scott RE. WhatsApp in clinical practice: a literature review. Stud Health Technol Inform. 2016;231:82-90.

13. Cobourne M, Sandler J and DiBiase A. Recommendations for Orthodontics during COVID-19 pandemic by British Orthodontic Society and the Faculty of Dental Surgery, Royal College of Surgeons of England;1-4. www.rcseng.ac.uk/dental-faculties/fds/coronavirus/

14. Linklater RA, Gordon PH. Bond failure patterns in vivo. Am J Orthod Dentofacial Orthop 2003;123:534-9.

15. Gyawali R, Pokharel PR, Giri J. Emergency appointments in orthodontics. APOS Trends Orthod 2019;9(1):40-43.

16. Ozcelik O, Haytac MC, Akkaya M. latrogenic trauma to oral tissues. J Periodontol 2005;76:1793-7.

17. Popat H, Rogers S, Eckhardt C, Knox J. Management of the casual orthodontic patient. Orthod Update 2010;3:9-13.

18. Wei J, Li Y. Airborne spread of infectious agents in the indoor environment. Am. J. Infect. Control. 2016;44:102-108.

19. Cleveland JL, Gooch BF. Transmission of blood-borne pathogens in US dental health care settings: 2016 update. J. Am. Dent. Assoc. 2016 (147) 729-738.

20. Kampf G, Todt D, Pfaender S, Steinmann E. Persistence of coronaviruses on inanimate surfaces and its inactivation with biocidal agents. J. Hosp. Infect. 2020.

21. Chen J. Pathogenicity and transmissibility of 2019-nCoV-a quick overview and comparison with other emerging viruses. Microb. Infect. 2020.

22. Harrel SK, Molinari J. Aerosols and splatter in dentistry: a brief review of the literature and infection control implications. J. Am. Dent. Assoc. 2004;135:429-437.

23. Liu L, Wei Q, Alvarez X, Wang H, et al. Epithelial cells lining salivary gland ducts are early target cells of severe acute respiratory syndrome coronavirus infection in the upper respiratory tracts of rhesus macaques. J. Virol. 2011; 85:4025-4030.

24. Meng L, Hua F, Bian Z. Coronavirus Disease 2019 (COVID-19): Emerging and Future Challenges for Dental and Oral Medicine [published online ahead of print, 2020 Mar 12]. J Dent Res. 2020;22034520914246.

25. CDC. 2020. "Coronavirus Disease 2019 (COVID-19)." Centers for Disease Control and Prevention. April 13, 2020. https://www.cdc.gov/ coronavirus/2019-ncov/hcp/dental-settings.html.

26. Rutala WA, Weber DJ, the Healthcare Infection Control Practices Advisory Committee (HICPAC). Guideline for disinfection and sterilization in healthcare facilities. (2008 (Update: May 2019)).

27. Heaton R. Sterilization of surgical instruments. Community Eye Health. 1998; 11(25):14-5. 